mendations of a specially appointed advisory committee, to a British chemist who shows outstanding promise as indicated by his or her published work. As on this oceasion there were two candidates adjudged to be of equal merit in different fields of work, it has been decided to make two awards of the Meldola Medal for 1964, and the recipients will be: Dr. J. S. Brimacombe, lecturer in chemistry in the University of Birmingham, in recognition of his work on the chemistry of carbohydrates and other hydroxylic compounds, with special reference to rare sugars; Dr. J. J. Rooney, lecturer in chemistry in the University of Hull, in recognition of his work in the field of heterogeneous catalysis, with special reference to the reactions of hydrocarbons.

\section{Simon Memorial Prize}

The Committee of the Low Temperature Group of the Institute of Physics and the Physical Society has announced that it has awarded the fourth Simon Memorial Prize to Prof. J. C. Wheatley of the University of Illinois, in recognition of his outstanding work on the properties of liquid helium-3 at very low temperatures. This Prize of $£ 250$ is awarded every 2 or 3 years for outstanding contributions in the field of low-temperature physics; it was established as a memorial to Sir Francis Simon. The presentation will be made during the Institute and Society's conference on "Solid State Physics" to be held in the Manchester College of Science and Technology during January 4-7, and Prof. Wheatley will deliver a lecture on "Helium-3 as a Fermi Liquid". Furtber information concerning conference and lecture can be obtained from the Meetings Officer, the Institute of Physics and the Physical Society, 47 Belgrave Square, London, S.W.1.

\section{Leverhulme Research Awards, 1965}

THe following fellowships and research grants, among others, tenable for periods of up to two years, have been announced by the Leverhulme Trustees: Fellowships, Dr. R. A. Donkin, lecturer in geography, University of Birmingham, for work on terracing and terraced agriculture in Middle America; Mr. B. E. B. Fagg, curator, Pitt Rivers Museum, Oxford, for a study of the Nok culture of Northern Nigeria. Research grants, Dr. P. Nield, development chemist, for studies in organic chemistry; Mr. C. T. Smith, Fellow and tutor of St. John's College and university lecturer in geography, University of Cambridge, for a study of the structure and development of rural settlement in the Peruvian Andes.

\section{Fellowships in Agricultural Marketing}

THE Ministry of Agriculture, Fisheries and Food is offering two fellowships in agricultural marketing, tenable from October 1965, normally for two years, at any university or other institution in the United Kingdom acceptable to the Ministry. The fellowships are designed for men or women of good honours degree standard who may have had industrial or commercial experience rather than research experience. The value of a fellowship will normally be between $£ 950$ and $£ 1,175$ per annum, exceptionally up to $£ 2,000$. Further information and forms of application can be obtained from the Advisory Service Division, Ministry of Agriculture, Fisheries and Food, Room 284, Great Westminster House, Horseferry Road, London, S.W.1.

\section{University and College News:}

Aberdeen

THe following lecturers have been appointed: Dr. J. R. Lewis and Dr. M. D. Ingram (chemistry); Dr. J. Duncan (mathematics).

\section{Edinburgh}

DR. R. W. D. Turner has been appointed reader in medicine. The following lecturers have also been appointed: Dr. G. Tennant (chemistry); Dr. M. H. I.
Baird (chemical engineering); Mr. D. Desbrow (mathematics).

DR. H. LIEBECK has been appointed senior lecturer in the Department of Mathematics. The following lecturers have also been appointed: Mr. G. T. Fielding (mathematics); Dr. E. B. Pattinson (physics); Dr. P. A. Floyd (geology).

\section{Lincoln College, University of Canterbury, New Zealand}

DR. S. N. ADAms, formerly in Tasmania with the Commonwealth Scientific and Industrial Research Organization working on soil aspects of cobalt deficiency, has been appointed director of the Tussock Grasslands and Mountain Lands Institute at the College.

Strathclyde

Mr. D. S. BUTLER, senior lecturer in the Department of Mathematics, has been appointed reader in numerical analysis. Mr. J. G. Fraser, lecturer in the Department of Mathematics, has been appointed senior lecturer.

Warwick

Dr. T. M. Sugden, director of the Shell Research Centre at Thornton, Cheshire, has been appointed to an associate professorship in the School of Molecular Sciences, as from October 1.

\section{Announcements}

Lord Murray of NwWhaven has been appointed director of the Leverhulme Trust Fund on the retirement of Sir Miles Clifford.

Prof. F. J. Dyson, professor of physics at the Institute for Advanced Study at Princeton, has been awarded the Dannie Heineman Prize of 2,500 dollars by the American Physical Society and the American Institute of Physics, for outstanding achievement in mathematical physics.

THE tenth annual meeting of the Health Physics Society will be held in Los Angeles during June 14-17. Further information can be obtained from W. L. Fisher, Health and Safety Laboratory, Atomics International, 8900 DeSoto Avenue, Canoga Park, California.

THE second international symposium on "Basic Environmental Problems of Man in Space", organized by the International Astronautical Federation and the International Academy of Astronautics, will be held in Paris during June 14-18. Further information can be obtained from the International Academy of Astronautics, 250 Rue Saint Jacques, Paris 5.

A conference on "Plastics in Building Structures", organized by the Plastics Institute in association with the Institution of Civil Engineers, the Institution of Structural Engineers and the Royal Institute of British Architects, will be held at the Institution of Electrical Engineers during June 14-16. Further informatiun can be obtained from the Plastics Institute, 6 Mandeville Place, London, W.1.

ERratum. In the communication entitled "Neuropathological Effects of Dosing Dogs with Isonicotinic Hydrazide and with its Methanosulphonate Derivative" by Dr. A. C. Palmer and Dr. P. R. B. Noel, which appeared on p. 506 of the January 30, 1965, issue of Nature, it was erroneously stated that "In two dogs dosed with the methanosulphonate at $10 \mathrm{mg} / \mathrm{kg} /$ day there was, however, severe laminar necrosis of the cerebral cortex, a change not seen with isoniazid". These two dogs in fact died during preliminary trials in which they received $30 \mathrm{mg} / \mathrm{kg} /$ day for six weeks and nine weeks respectively, and not at the subsequent group dosage level of $10 \mathrm{mg} / \mathrm{kg} / \mathrm{day}$, and the authors apologize for the unfortunate impression that may have been created. The full details of this experiment are to be recorded in a separate communication elsewhere. 